\title{
Ownership Structure and Earnings Management of Listed Conglomerates in Nigeria
}

\author{
Musa Adeiza Farouk ${ }^{\star 1}$ and Nafiu Muhammad Bashir ${ }^{2}$ \\ ${ }^{1}$ Department of Accounting, Ahmadu Bello University, Zaria, Nigeria \\ ${ }^{2}$ Department of Business Administration, Ahmadu Bello University, Zaria, Nigeria
}

\begin{abstract}
Earnings management is a critical issue in developed and developing countries. In Nigeria, the issue is left under the disguise of business ethics. Only the financial sector of the economy is under close surveillance to check the earning management excesses. Even though earning management does not violate accounting rules, its practice is ethically questionable. Therefore, the study examines the effect of ownership structure on earnings management of listed conglomerates in Nigeria. Ownership structure is represented with managerial ownership, institutional ownership, block ownership and foreign ownership, while earnings management is measured using modified Jones model by Dechow, Sloan and Sweeney (1995). The robust ordinary least square technique was used while Stata 13 was adopted as a tool for the analysis. Data were obtained from the secondary source through the firm's annual reports and accounts. The entire six listed conglomerates on the Nigerian Stock Exchange were used covering the period 2008-2014. The findings show that managerial ownership and ownership concentration have a significant and negative effect on earnings management of listed conglomerates in Nigeria, while foreign ownership recorded positive and significant effect on earnings management of firms, institutional ownership was however reported to have an insignificant but negative influence on earnings management. The study, therefore, recommends that management should be encouraged to have more interest through shares in the organisation as it enables them to have more sense of belonging, which in turn will help mitigate their opportunistic tendencies.
\end{abstract}

Keywords: Ownership Structure, Earnings Management, Listed Conglomerates, Developing Country

JEL Classification: M41, M42, J16, M42, G39

Paper Type: Research Paper

* Corresponding author: E-mail: musafarouk@yahoo.com 


\section{INTRODUCTION}

Many scholars have identified relevance and reliability as the critical qualitative characteristics determining the usefulness of accounting information for making economic decisions (Houqe, Dunstan, Karim, \& Zijl, 2010). Accounting earnings information is relevant when it influences user's decisions by helping to form predictions and confirm or correct past judgments (Houqe et al., 2010). Accounting earnings information is reliable if it can be depended upon to represent faithfully, without bias or undue error, the transactions or events that it professes to represent (FASB 1980: SFAC 2).

The quality of accounting information is influenced by an array of factors, most of which stem from the demand for such information for use in contractual arrangements and from the incentives and opportunities of management to manage the reported numbers (Gabrielson, Gramlich \& Plenborg, 2002). To minimise the occurrence of earnings management measures, then the company needs to implement good corporate governance mechanisms through the system of control and management of the company. Poor corporate governance practices are often blamed for being one cause of the crisis. Ownership structure has been identified by extant literature to be useful mechanisms through which management excessiveness in respect of reported accounting numbers can be checked. This ownership structure can be categorised into two groups: the proportion of shares owned by insiders and outsiders; the proportion of shares owned by institutional versus individual shareholders (Parveen, Malik, Mahmood, \& Jan 2016). The level of shares held by these categories of owners could give them control and incentives to monitor the management from embarking on self-serving interest as against the interest of the other shareholders. In some quarters, it has been argued that shares held by management could also determine the extent to which they manage the organisation as it is a variable that might reduce the agency costs as the motivations of managers are aligned closely to the objectives of other shareholders.

Institutional investors are significant investors, other than a natural person, who exercises discretion over the investment of others. Institutional investors have the opportunity, resources and ability to monitor, discipline and influence a manager's decision in the firm (Monks \& Minow, 1995). Also, literature posits, managers of firms that are highly concentrated stand the chance to be highly monitored (Ramsey \& Blair, 1993). A firm is said to be highly concentrated if a significant portion of its equity is in the hands of few individuals (Usman \& Yero, 2012; Roodposhti \& Chasmi, 2010). Few individuals with more stakes have more reasons to be worried about their investments, and hence monitor the management of the firm's affairs. However, other studies documented evidence suggesting that ownership concentration induces earnings management (Halioui \& Jerbi, 2012). The argument here is that substantial shareholder can pressure the managers to improve earnings so that their market value may improve, and due to this excessive pressure, the managers will then have to resort to earnings management.

The managers may also be motivated to engage in earnings management to signal well to the foreign investors. The level of shares held by foreign could influence the direction of management regarding reported accounting earnings. Empirical studies on the relationship between ownership structure and reported earnings management have reported unclear results and did not conclusively determine whether ownership structure affects earnings management. On the one hand, several studies evidence supports the significant impact of stock ownership by management and institutions on earnings management (Velury \& Jenkins, 2006; Koh, 2007 \& Soongso (2012)). On the other hand, the evidence contained in Sirger and Utama (2008), Salsiah et al. (2008) and Omar and Hind (2012) and demonstrate that institutional and managerial ownership are not significantly related to the quality of earnings. Given these mixed and inconclusive results, 
which are of foreign origin, we intend to find out to what extent that ownership structures impact on earnings management in an emerging economy such as Nigeria?

Conglomerates sector in Nigeria is very important to the economy as a source of employment and economic growth. Therefore, understanding the characteristics of the ownership structure that influences the level of earnings management within this sector is vital to enhance the reliability and transparency of reported accounting numbers. Most research in this area is conducted in chemical and paints sector, and banking sector (Farouk \& Shehu, 2012; Farouk, 2014). Therefore, our research has chosen to cover the listed conglomerates in Nigeria. These are the important issues that inform the thrust of this study. Therefore, the study seeks to ascertain the extent to which the ownership structure influences the earnings management of listed conglomerates in Nigeria.

\subsection{Objectives of the Study}

The primary objective of this study is to examine the effect of ownership structure on the earnings management of listed conglomerates in Nigeria. The specific objectives are:

i. To determine the impact of managerial ownership on the earnings management of the listed conglomerates in Nigeria.

ii. To assess the effect of institutional ownership on the earnings management of the listed conglomerates in Nigeria.

iii. To examine the influence of ownership concentration on the Earnings Management of the listed conglomerates in Nigeria.

iv. To determine the effect of foreign ownership on the earnings management of the listed conglomerates in Nigeria.

\section{LITERATURE REVIEW AND HYPOTHESES DEVELOPMENT}

This section is dedicated to the review of empirical literature and development of research hypotheses following the argument advanced by various scholars in this area.

\subsection{Managerial Ownership and Earnings Management}

Managerial ownership is an important device in aligning manager's interests with those of shareholders, and therefore, improved earnings management (Warfield et al. 1995). The supporters of agency theory believe that managerial ownership of equity help in alleviating moral hazard problem between managers and shareholders, and managers with large stake of equity are less likely to involve in self-interested action because value decreasing behaviour is costly for them (Jensen \& Mekling, 1976). Aygun, Suleyman and Sayim (2014) found that managerial ownership has a positive effect on earnings management. Alzoubi (2016) study revealed that insider managerial ownership has a superior influence on financial reporting quality, as it is, to a greater extent, potentially able to curtail earnings management. Ogbonnaya, Chidiebere and Ihendinihu (2016) found managerial ownership to have a significant positive effect on earnings management. Ayadi (2014) investigated the relationship between ownership structure and earnings quality in the French context and found that earnings management has a positive and significant effect on earnings management. Similarly, Obigbemi (2017) study documented a positive effect of management ownership on earnings management of companies in Nigeria.

Bradbury, Mak and Tan (2006) study provided similar findings in which their results indicate that the reliability of financial information improves as managerial ownership increases. Sanchez-Ballesta and Garsa-Meca (2007) examine the relationship between ownership structure and discretionary accruals for a sample of Spanish non-financial 
companies. Their results support the hypothesis that insider ownership contributes to the constraining of Earnings Management when the proportion of shares held by insiders is not too high. When insiders own a large percentage of shares, however, they are entrenched and the relation between insider ownership, discretionary accruals reverses. Morck, Shleifer and Vishny (1988) argue that greater ownership would provide managers with deeper entrenchment and, therefore, the higher scope for opportunistic behaviour.

Hutchinson and Leung (2007), Pizzaro, Mahenthiran, Cademarton and Curci (2007), and Johari, Saleh, Jafar and Hassan (2008) studies reported similar findings in which they conclude that firms with high management ownership of equity are more likely to experience earnings of low quality because their managers engage in self-interested behavior of earnings management. In addition to the significant results, empirical studies on the relationship between managerial ownership and the reporting quality of earnings numbers have reported insignificant findings. For example, a research conducted by Korczak (2004), Velury and Jenkins (2006), and Chang and Sun (2008) reveals that management ownership and Earnings Management is not significantly correlated. Liu and Lu (2007) do not find any significant impact of managerial ownership on the reliability of earnings information. Based on the argument from various scholars, this study hypothesised that:

$\mathrm{H}_{1}$ Managerial ownership has no significant impact on the Earnings Management of quoted Conglomerates firms in Nigeria.

\subsection{Institutional Ownership and Earnings Management}

Alzoubi (2016) found that institutional ownership has a significant negative influence on earnings management of firms. Aygun, Suleyman and Sayim (2014) examined the effects of corporate ownership structure and board size on earnings management in Pakistan firms. It was found that institutional ownership has a negative effect on earnings management. Liu and Tsai (2015) examine board member characteristics and ownership structure impacts on real earnings management from Taiwan. They found that institutional ownership has negative and significant effect in curtailing real earnings manipulation.

Wang (2006) stated that ownership structure has important effects on reported earnings. However, the influence of insiders and institutional investors on the ability of managers to manipulate earnings remains a controversial issue. Institutional investors, relative to individual investors, have more capability of gathering, interpreting financial reports and detecting managerial opportunism over earnings numbers. They are also interested in monitoring a firm's financial reporting quality when investing heavily in the firm (Chung, Firth \& Kim, 2005). The current monitoring hypothesis views institutional investors as long-term investors with raving incentives and motivations to closely monitor management action (Jung \& Kown, 2002). Consistent with this notion, Velury and Jenkins (2006) provided evidence that firms' with high stock ownership by institutions experience earnings numbers of high quality. Koh (2007) documented similar findings and concluded that active institutional investors are more likely to effectively constrain the unethical behaviour of earnings management and enhance the credibility and reliability of financial reporting.

Empirical research findings revealed that the quality of financial reporting impaired as institutional ownership of equity increases (Bradbury et al., 2006, Pizzaro et al., 2007). Sirger and Utama (2008) and Lin and Hwang (2010) document similar findings in which they provided no empirical support that high equity holdings by institutions enhance the reliability of financial information. Based on the findings from the extant literature. This study hypothesised that: 
$\mathrm{H}_{2}$ Institutional ownership has no significant effect on the Earnings Management of quoted Conglomerates firms in Nigeria.

\subsection{Ownership Concentration and Earnings Management}

Small number shareholders would not be much interested in monitoring because they would bear all the costs implication for mentoring the activities of the management when they only have little or no much gain (Sandra, 2012). Iturriaga and Hoffmann (2005) found that ownership concentration reduces the managers' discretionary behaviour. Alzoubi (2016) documented that external blockholder to a greater extent has potential in curtailing earnings management of firms. Ayadi (2014) reported a significant positive impact of ownership concentration on earnings informativeness. Obigbemi (2017) examine the effect of ownership structure and earnings management practices of Nigerian companies. It was found that block ownership has a significant negative effect on earnings management of companies.

Large shareholders may intervene in the firm's management and may encourage managers to engage in earnings management to maximise their private benefits (Jaggi \& Tsui 2007). As managers fear negative repercussions for declining performance from large shareholders, they may also have a strong motivation to engage in earnings management. Choi, Jean and Park (2004) and Kim and Yoon (2008) documented that earnings management is positively related to ownership concentration. Zhong et al., (2007) studied the association between outside block-holder ownership and earnings management for NYSE firms. Their results indicate that outside block-holder ownership is positively associated with discretionary accruals for firms that face declining pre-managed earnings. Following the review of literature in respect of ownership concentration and earnings management. The study hypothesised that:

$\mathrm{H}_{3}$ Ownership Concentration has no significant influence on the Earnings Management of quoted Conglomerates firms in Nigeria.

\subsection{Foreign Ownership and Earnings Management}

Foreign investment is considered to be associated with better monitoring, and hence expected to reduce the private benefits of control. Most studies found that foreign institutional ownership is associated with lower earnings management. Omar and Hind (2012) found that firms with foreign or local institutions as the largest shareholders engage in significantly lower earnings management than other firms. Frydman, Gray, Hessel \& Rapaczynski, 1999) posited that foreign owners have the financial resources, managerial know-how, and corporate governance expertise that give them an advantage over other owners in monitoring insiders and report a positive association between foreign ownership and post-privatisation corporate performance. Alzoubi (2016) study found that foreign ownership has a significant negative effect on earnings management of listed firms in Jordan.

Also in D'Souza et al. (2005) found evidence suggesting that greater foreign ownership results in greater efficiency gains in privatised firms. Therefore, foreign ownership which may be associated with better monitoring reduces the ability of insiders to manipulate earnings for private purposes. Based on the above findings reported in respect of foreign ownership and earnings management. The study hypothesised that:

$\mathrm{H}_{4}$ Foreign Ownership has no significant effect on the Earnings Management of quoted Conglomerates firms in Nigeria. 


\section{THEORETICAL FRAMEWORK}

The Agency theory view directors as the agent of the shareholders, and therefore, there is a need for them to act in the best interest of the shareholders. In this situation, sometimes the agent may not act in the best interest of the shareholders, which result in an agency loss situation. The agency theory stressed the separation of ownership (principal) and managers (agent) in an organisation. Therefore, it is believed that managers may sometimes pursue opportunistic behaviour which may conflict with the goal of the owners (principals) and therefore destroy the wealth of the shareholders. Advocates of the agency approach view the manager (directors) as an economic institution that will mitigate the problems and serves as the guardian to shareholders (Fama \& Jensen, 1983). This study adopted agency theory due to its relevance in resolving the conflict that may arise between managers (agent) and shareholders (principal) of the companies, its empirical evidence by the study conducted by several scholars on ownership structure and earnings management in developed countries will link the variables concern in the Nigerian situation. Critical postulations of agency theory serve as the bases for the adoption.

\section{METHODOLOGY}

The study adopted correlational design. The study used a secondary source of data which was obtained from the firm's Annual report and accounts from 2008 to 2014 . The study is limited to six Conglomerates (A.G Leventis, John Holt, Challarams, SCOA, UAC and Transnational Corporation of Nigeria) listed in the Nigerian Stock exchange as at $31^{\mathrm{t}}$ December 2014. Robust Ordinary Least Squares (OLS) estimation is used in the study. The technique used is considered appropriate in that it is better in determining the relationship between ownership structure and earnings management.

\subsection{Earnings Management Measurement}

This study adopts the modified Jones model by Dechow, Sloan and Sweeney (1995) which are:

$\mathrm{DACC}_{i t}=\mathrm{TACC}_{\mathrm{it}} / \mathrm{TA}_{\mathrm{it}-1}-\left[\alpha_{1}\left(1 / \mathrm{TA}_{\mathrm{it}}-1\right)+\alpha_{2}\left[\left({ }^{\Delta \mathrm{REV}} \mathrm{V}_{\mathrm{it}}-\mathrm{REC}_{\mathrm{it}} / \mathrm{TA}_{\mathrm{it}-1}\right)\right]+\alpha_{3}\left(\mathrm{PPE}_{\mathrm{it}} / \mathrm{TA}_{\mathrm{it}-1}\right)\right]$

The study used the absolute measure of discretionary accruals from the residual as a proxy for the extent of opportunistic earnings management.

Table 1. Explanatory Variable Measurement

\begin{tabular}{cll}
\hline Variable & Proxy (ies) & Measurement \\
\hline $\begin{array}{l}\text { Ownership } \\
\text { structure }\end{array}$ & Managerial Ownership & $\begin{array}{l}\text { \% of Total Shares held by Directors (Karathanssis \& } \\
\text { Drakos, 2004) }\end{array}$ \\
,, & $\begin{array}{l}\text { Institutional Ownership } \\
\text { \% of Total Shares held by Institutions (Koh, 2003) } \\
\% \text { of those who have up to 5\% or more in the total } \\
\text { shares in issue (SEC, 2011) }\end{array}$ \\
Ownership concentration & $\begin{array}{l}\text { \% of Total Shares held by foreign investors (Farouk, } \\
\text { 2014) }\end{array}$ \\
Share price & Foreign Ownership & $\begin{array}{l}\text { Average of three-month share price for all the } \\
\text { companies within a particular year. }\end{array}$ \\
Firm size & Control variable & Natural logarithm of total assets \\
\hline
\end{tabular}




\subsection{Control Variable Justification}

Control variable was introduced into the variable to avoid misspecification error since similar empirical work posited that discretionary accrual models that are not controlled are often misspecified (Roodposhti \& Chasmi, 2010).

\subsection{Model Specification}

Given the discussion above, the various hypothesis and variables are combined into a functional relation to explaining the relationship between ownership structure and earnings management. The empirical form of the model is:

$\mathrm{DACCR}_{\text {it }}=\beta_{0}+\beta_{1} \mathrm{MGROS}_{\text {it }}+\beta_{2} \mathrm{INST}_{\text {it }}+\beta_{3} \mathrm{OWNCONS}_{\text {it }}+\beta_{4} \mathrm{FROW}_{\text {it }}+\beta_{5} \mathrm{SIZE}_{\text {it }}+\beta_{6} \mathrm{SP}_{\text {it }}+\varepsilon_{\text {it }}$

Where,

EM is Earnings Management measured by discretionary accruals (DACCR).

MGROS is (managerial) ownership,

INST is institutional ownership,

OWNCONS is Ownership concentration,

FROW is foreign ownership.

SIZE is Firm Size,

$\mathrm{SP}$ is Share Price,

$\beta o$ Is Intercept,

$\beta_{1}, \beta_{2}, \beta_{3}, \beta_{4}, \beta_{5}, \beta_{6}$ are Coefficient and

$\mathrm{e}$ is the error term.

\section{RESULTS AND DISCUSSION}

This section deals with the preliminary analysis of the sample using descriptive statistics and correlation matrix. This was followed by the presentation, analysis, interpretation and discussion of findings.

\subsection{Descriptive Statistics}

The sample descriptive was presented in Table 2 where the minimum, maximum, mean, and standard deviation of the data for the variables used in the study were described.

Table 2. Descriptive Statistics

\begin{tabular}{lcccccc}
\hline Variables & Minimum & Maximum & Mean & $\begin{array}{c}\text { Standard } \\
\text { Deviation }\end{array}$ & Skewness & Observation \\
\hline DACCR & 0.25 & 72.87 & 8.4895 & 12.47580 & 3.611298 & 42 \\
MGROS & 0.16 & 0.50 & 0.2719 & 0.08211 & 0.934448 & 42 \\
INST & 0.00 & 0.74 & 0.4212 & 0.20162 & 0.130912 & 42 \\
OWNCONS & 0.25 & 0.83 & 0.6100 & 0.17315 & -0.75098 & 42 \\
FROW & 0.00 & 0.50 & 0.2048 & 0.18079 & 0.380787 & 42 \\
FSIZE & 11.25 & 19.73 & 15.919 & 1.66996 & -0.57083 & 42 \\
SP & 1.99 & 227.9 & 42.329 & 53.9512 & 1.836274 & 42 \\
\hline
\end{tabular}

Table 2 shows that on average, during the period of the study, the Managerial Ownership has a mean value of $27 \%$, Institutional Ownership has an average of $42 \%$, Ownership concentration has a mean value of $60 \%$, and foreign ownership has a mean value of $71 \%$. This implies that only Ownership concentration and foreign ownership have ownership above 50\%, while Managerial and Institutional Ownership are below 50\%. Managerial 
Ownership has a minimum value of $16 \%$ and a maximum value of $50 \%$. Institutional Ownership has a minimum value of Zero (0) and a maximum value of $74 \%$. The minimum value of Institutional Ownership implies that there is a particular year that the firm's do not have institutional investors. Ownership Concentration has a minimum value of $25 \%$ and a minimum value of $83 \%$. Amongst the Independent variables, the Institutional ownership has the highest standard deviation of 0.20162 signifying its low contribution in constraining earnings management in listed Conglomerates firms' in Nigeria. While foreign ownership has the lowest standard deviation among the significant variables which indicate its higher contribution in restraining earnings management in listed Conglomerates firms in Nigeria. The results show that all the variables have mean values greater than their respective standard deviation, except for dependent variable (discretionary accruals) and share price used as control variable implying higher than normal peak. The skewness result which was largely around zero and one indicates that the data are typically distributed.

\subsection{Correlation Matrix}

The correlation matrix is used to determine the relationship between the dependent variable and independent variables of the study. Table 3 presents the correlation matrix for the sample observations.

Table 3. Correlation Matrix

\begin{tabular}{llllllll}
\hline & DACCR & MGROS & INST & OWNCONS & FROW & FSIZE & SP \\
\hline DACCR & 1 & & & & & & \\
MGROS & -0.014 & 1 & & & & & \\
INST & 0.180 & -0.325 & 1 & & & & \\
OWNCONS & 0.098 & -0.133 & -0.111 & 1 & & & \\
FROW & 0.218 & -0.316 & 0.480 & -0.114 & 1 & \\
FSIZE & -0.444 & -0.302 & -0.019 & -0.471 & 0.319 & 1 & 1 \\
SP & 0.1565 & -0.047 & 0.417 & 0.304 & 0.123 & -0.371 & 1 \\
\hline
\end{tabular}

Table 3 indicates that there is a positive relationship between all the independent variables (ownership structure) and discretionary accruals except for managerial ownership that is negatively related. The one of the control variable (firm size) used in the study has a negative relationship with earnings management of the listed Conglomerates firms in Nigeria. This implies that ownership structures proxies are contributing positively and negatively to the earnings management of listed Conglomerates firm in Nigeria. The correlations between the independent variables themselves are not expected to be significant. Six of the independent variables are negatively related while the remaining four are positively related.

The tolerance value and the variance inflation factor are two good measures of assessing multicollinearity between the independent variables in the study. From the regression result, the variance Inflation factor were consistently smaller than ten (Table 4) indicating the complete absence of multicollinearity (Cassey \& Anderson, 1999). This shows the appropriateness of our study model being fitted with the four independent variables. Also, the tolerance values were consistently smaller than 1.00 , thus further substantiates the fact that there is a complete absence of multicollinearity between independent variables (Tobachmel \& Fidell, 1996).

\subsection{Robustness Test}

To make better the validity of all statistical inferences to be drawn from the study, this section presents the result of robustness test conducted. The robustness test included 
multicollinearity test, heteroscedasticity test, Hausman specification test and Normality test.

\subsubsection{Multicollinearity test}

The variance inflation factor and tolerance values were found to be consistently smaller than 10 and 1 respectively, indicating that multicollinearity was not a problem (Tobachnick \& Fidell, 1996; Cassey \& Anderson, 1999).

\subsubsection{Heteroscedasticity Test}

The result obtained from the heteroscedasticity test shows chi-square value of 40.30 which was large and the p-value of 0.0000 which was small, indicating heteroscedasticity was present necessitating further test.

\subsubsection{The Hausman test}

The result obtained from the Hausman specification test conducted indicates, that $(p>$ 0.05 ) and as such the random effect model should be used in favour of the fixed effect model.

\subsection{Regression Result}

The results of GLS about the effect of Ownership structure on earnings management of listed conglomerates in Nigeria were discussed. The summary of regression results is presented in Table 4.

Table 4. Summary of Regression Result

\begin{tabular}{llllll}
\hline Variables & Coefficient & t-Stat & t-sig & Cumulative Result & Tolerance / VIF \\
\hline Constant & 114.659 & 3.30 & 0.002 & & \\
MGROS & -26.269 & -1.73 & 0.092 & & $0.664 / 1.51$ \\
INST & -5.521 & -0.78 & 0.440 & & $0.521 / 1.92$ \\
OWNCONS & -16.101 & -2.27 & 0.029 & & $0.592 / 1.69$ \\
FROW & 30.268 & 3.04 & 0.004 & & $0.648 / 1.54$ \\
SIZE & -5.793 & -2.66 & 0.012 & & $0.509 / 1.97$ \\
SP & -0.020 & -0.53 & 0.596 & & $0.648 / 1.54$ \\
& & & & 0.39 & \\
R $^{2}$ & & & & 4.84 & \\
F-Statistic & & & & 0.00 & \\
F-Significance & & & & 1.69 & \\
Mean VIF & & & & & \\
\hline
\end{tabular}

Cumulatively, in Table 4, it is observed that the coefficient of determination for the regression as depicted by the $R^{2}$ value of 0.3901 suggests that about $39 \%$ of the systematic variation of the dependent variable is accounted for by the explanatory variables. The F-statistic of 4.84 shows that the model of the study is well fitted. This can be further confirmed by the significant value of 0.0011 which shows that the cumulative impact of the regressors was significant at $1 \%$, which implies that ownership structure of Conglomerates firms in Nigeria except for institutional ownership has strongly and significantly impacted on the earnings management.

From Table 4, it is observed that the t-value for managerial ownership (MGOS) is 1.73 and a beta value of -26.269 with a significant value of 0 . 092 . This signifies that managerial ownership is significant, negatively and strongly influencing earnings management of listed Conglomerates firms in Nigeria. This implies that for every one percent $(1 \%)$ increase in managerial ownership, the earnings management of listed Conglomerates firms will decrease by 26.27 . This may be as a result the argument put 
forward by the advocate of the alignment hypothesis that as management ownership increases, their interests will be more closely aligned with owners and the need for intense monitoring by the board should decrease.

The result, therefore, provides evidence of rejecting null hypothesis 1 of the study which states that managerial ownership has no significant impact on the earnings management of listed Conglomerates firms in Nigeria. The findings are in line with Saleh et al. (2005) and Bradbury et al. (2006). However, the empirical works of Liu and Lu (2007), Pizzaro et al. (2007), Johari et al. (2008) and Chang and Sun (2008) are in contrast with this study findings.

Institutional ownership as depicted in Table 4 shows t-value of -0.78 and a beta value of -5.521 with an insignificant value of 0.440 . This signifies that institutional ownership has no any significant impact in influencing earnings management of listed Conglomerates firms in Nigeria. The result, therefore, provides evidence of failing to reject the null hypothesis 2 of the study which states that Institutional ownership (INOS) has no significant relationship and impact on earnings management of listed Conglomerates firms in Nigeria. The finding is in line with the study of Sirger and Utama (2008), and Lin Hwang (2010) but contrary to the works of Velury and Jenkins (2006), Koh (2007) and Pizzaro et al. (2007).

The Ownership concentration showed a t-value of -2.27 and a beta value of -16.101 with a significant value of 0.029 . This signifies that Ownership concentration (OWNCONS) has a significant negative influence on earnings management of listed Conglomerates firms in Nigeria. It implied that when there is one percentage increase (1\%) in ownership concentration, the earnings management of listed Conglomerates firms will decrease by 16.10. This may be as a result of the efficient monitoring hypothesis as cited in the literature which suggests that large shareholders have a strong incentive to actively monitor and influence firm management to protect their significant investments. Therefore, ownership concentration may reduce agency costs by increasing monitoring and alleviating the free-rider problem. Also, there may be less pressure on management to meet short-term earnings expectations because controlling shareholders focus more on the long term. The result, therefore, provided evidence of rejecting the null hypothesis $\mathrm{H} 3$ of the study which states that Ownership concentration has no significant impact on earnings management of listed Conglomerates in Nigeria. This finding is in line with Iturriaga and Hoffmann (2005) but in contrast with what other studies revealed, such as the works of Jaggi and Tsui (2007) and Kim and Yoon (2008).

The Foreign ownership showed a t-value of 3.04 and a beta value of 30.268 with a significant value of 0.004 . This signifies that Foreign Ownership (FROW) strongly but positively drives earnings management of listed conglomerates in Nigeria. It implies that when there is an increase in foreign ownership, the earnings management of listed conglomerates will increase by N30.27. This may be that those foreign firms do not have financial resources, managerial know-how, and corporate governance expertise which ought to have to give them an advantage over other owners in monitoring insiders and the reported earnings. The foreigners may only be interested in the short-term returns from these firms and therefore prefer to leave the firm bleeding. The result, therefore, provides evidence of rejecting our null hypothesis $\mathrm{H} 4$ of the study which states that Foreign Ownership has no significant contribution to earnings management of listed conglomerates in Nigeria. While this finding may be a striking revelation, it is however in contrast to the findings of Omar and Hind (2012) and D'Souza et al. (2005).

The Firm Size shows a t-value of -2.66 and a beta value of -5.793 with a significant value of 0.012 . This signifies that Firm Size (FSIZE) is significant, negatively and strongly influencing earnings management of listed conglomerates in Nigeria. It implies that when there is an increase in a total asset of the firm, the earnings management of listed 
conglomerates will decrease by 5.79. This may be as a result of the fact that as the firm acquire more assets and utilises it judiciously in achieving higher profit for the firm, they may not be needed for management to smooth their earnings since they have assets that can generate profit for the firm.

From Table 4, it is observed that the t-value for share price (FP) is -0.53 and a beta value of -0.020 with a significant value of 0.596 . This signifies that share price is insignificant, negatively and weakly influencing earnings management of listed conglomerates in Nigeria. This implies that for any increase in share price, the earnings management of listed conglomerates may not have any significant changes. This may be as a result of the fact that share price itself may be driven earnings manipulations by managers.

\section{CONCLUSION AND RECOMMENDATIONS}

Based on the findings of the study, the study concludes that ownership structure influences earnings management of listed conglomerates except for Institutional ownership found to have no significant impact on the earnings management. Overall, this study is an important extension of prior research examining the financial reporting quality effect of ownership structure for non-financial institutions. It enhances the understanding of the role of ownership structure in constraining Earnings Management, and it has potentially important policy implications for the institutions' reformers and regulators who are striving to improve transparency and quality of financial reporting in the sector.

From the conclusions of the study, managers should be encouraged to have more interest through shares in the organisation as it enables them to have more sense of belonging, which in turn may help mitigate their opportunistic tendencies. Also, the institutional ownership should be improved upon through allocation of more shares as the negative sign is an indication that institutional investors could help in mitigating earnings management.

The study further concluded that firms should be encouraged to maintain a high number of concentrated ownership at an average of $61 \%$ or above as the ownership concentration is indeed power and the most reliable ownership structure in preventing the management's tendencies for opportunistic behaviour (earnings management). Lastly, foreign ownership, another ownership structure, has been found to increase earnings manipulation by management. Therefore, the foreigner should be giving close monitoring while on the board as their presence may encourage management to engage in earnings management just to signal that the company is doing well.

\section{REFERENCES}

Alzoubi, E.S.S. (2016). Ownership structure and earnings management: evidence from Jordan. International Journal of Accounting \& Information Management, 24(2), 135-161.

Ayadi, W.M. (2014). The relationship between ownership structure and earnings quality in the French context. International Journal of Accounting and Economics Studies, 2(2), 80-87

Aygun, M., Suleyman, I., \& Sayim, M. (2014). The Effects of Corporate Ownership Structure and Board Size on Earnings Management: Evidence from Turkey. International Journal of Business and Management, 9(12), 123-132

Bradbury, M., Mak, Y. T., \& Tan, S. M. (2006). Board Characteristics, Audit Committee characteristics and abnormal accruals. Pacific Accounting Review, 18(2), 47-68.

Casey, K.M., \& Anderson, D.C. (1999). Examining the Impact of the Tax Reform Act on Corporate Dividend Policy: A New Methodology, Journal of Financial Review, 34(3), 17- 28. 
Chang, J.L., \& Sun, H.L. (2008). The Relations between Earnings Informativeness, Earnings Management and Corporate Governance in the Pre and Post Box Records. 1-48. Retrieved from http"/issm.com/abstract1299221.

Choi, J.H., Jean, K.A., \& Park, J. (2004). The role of audit committees in decreasing earnings management: Korean evidence', International Journal of Accounting, Auditing and Performance Evaluation, 1(1), 37-60.

Chung, R., Firth, M., \& Kim, J. (2005). Earnings Management, Surplus Free Cashflow and External Monitoring. Journal of Business Research, 58(6), 766-776.

Dechow, P.M., Sloan R.G. \& Sweeney, A.P. (1995). Detecting earnings management. The Accounting Review, 70(2), $193-225$

D'Souza, J., \& Megginson, W. (1999). The financial and operating performance of privatised firms during the 1990s. Journal of Finance, 54, 1397-1438.

Farouk, M. A., \& Shehu, U. H. (2012). Equity Possession and Monitoring Features Influence the Performance of Listed Chemical and Paints Firms in Nigeria. Accounting Frontier, 14(2), 1533.

Farouk, M. A. (2014). Possession Formation and Earnings Management of Listed Chemical and Paints Firms in Nigeria. Being an M.Sc Thesis presented to the school of postgraduate studies, Ahmadu Bello University, Zaria.

Fama, E., \& Jensen, M. (1983). Separation of Ownership and Control. Journal of Law and Economics, 26, 301-325.

Frydman, R., Gray, C., Hessel, M., \& Rapaczynski, A. (1999). When does privatisation work? The impact of private ownership on corporate performance in transition economies. Quarterly Journal of Economics, 114, 1153- 1191.

Gabrielsen, G., Gramlich, J., \& Plenborg, T. (2002). Managerial ownership, the information content of earnings, and discretionary accruals in a non-US setting. Journal of Business, Finance and Accounting, 29, 67-89

Halioui, K., \& Jerbi, A. (2012). The Effects of Blockholders on Earnings Management: The Case of Tunisian Listed Firms. International Journal of Multidisciplinary Research, 2(2), 1-16.

Houqe, M. N., van Zijl, T., Dunstan, K., \& Karim, A. W. (2012). The effect of IFRS adoption and investor protection on earnings quality around the world. The International Journal of Accounting, 47(3), 333-355.

Hutchinson, M., \& Lang, S. (2007). An Investigation of Factors Influencing the Association between top Management Ownership and Earnings Management. Journal of Contemporary Accounting and Economics, 3(2), 130-153.

Iturriaga, F.J.L., \& Hoffmann, P.S. (2005). Earnings management and internal mechanisms of corporate governance: Empirical evidence from Chilean firms. Corporate Ownership \& Control, 3(1), 17-29.

Jaggi, B., \& Tsui, J. (2007). Insider trading earnings management and corporate governance: Empirical evidence based on Hong Kong Firms. Journal of International Financial Management and Accounting, 18(3), 192-222.

Jensen, M., \& Meckling, W. (1976). Theory of the firm: managerial behaviour, agency costs and ownership structure. Journal of Financial Economics, 3, 24-34.

Jung, K., \& Kown, S.Y. (2002). Ownership Structure and Earnings Informativeness. Evidence from Korea. The International Journal of Accounting, 37(3), 301-325

Korczak, A. (2004). Managerial Ownership and Informativeness of Accounting Numbers in a European Smarting Market. 1-30. Retrieved from http://ssm.com.abstract-405123

Koh, (2007). Institutional investor type, Earnings Management and Benchmark beaters. Journal of Accounting and Public Policy, 26(3), 267-299

Karathanssis, G.A., \& Drakos, A.A. (2004). A Note on Equity Ownership and Corporate Value in Greece. Journal of Finance and Economics, 3, 305-360.

Kim, H.J., \& Yoon, S.S. (2008). The impact of corporate governance on earnings management in Korea. Malaysian Accounting Review, 7(1), 43-59.

Lin, J.W., \& Hwang, M. (2010). Audit quality, corporate governance, and earnings management: A Meta-Analysis. International Journal of Auditing, 14, 57-77.

Liu, Q., \& Lu, Z. (2007). Corporate Governance and Earnings Management in the Chinese Listed Companies. Journal of Corporate Finance, 13, 881-906. 
Liu, J., \& Tsai, C.C. (2015). Board Member Characteristics and Ownership Structure Impacts on Real Earnings Management: Evidence from Taiwan. Accounting and Finance Research, 4(4), 86-96

Monks, R., \& Minow, N. (1995). Corporate governance. Blackwell. Cambridge. M.A.

Morck, R., Shleifer, A., \& Vishny, R. (1988). Management ownership and market valuation: An empirical analysis. Journal of Financial Economics, 20, 293-315

Obigbemi, I. F. (2017). Ownership Structure and Earnings Management Practices of Nigerian Companies. Journal of Internet Banking and Commerce, 22(S8), 2-8.

Ogbonnaya, A.K., Chidiebere Ekwe, M., \& Ihendinihu, J.U. (2016). Effect of Corporate Governance and Ownership Structure on Earnings Management Of Brewery Industry. European Journal of Accounting, Auditing and Finance Research, 4(7), 35-45.

Omar, F., \& Hind, E. (2012). Ownership Structure and Earnings Management: Evidence from Casablanca Stock Exchange. From the selected works of Omar Farooq. Aalborg University, Denmark.

Parveen, S., Malik, N., Mahmood, Y., \& Jan, F. A. (2016). Impact of Ownership Structure on Earnings Management: Evidence from Pakistani Banking Sector. Journal of Poverty, Investment and Development, 23, 24-34.

Pizzaro, V., Mahenthiran, S., Cademarton, D., \& Curci, R. (2007). The influence insiders and institutional owners of the value transparency and Earnings quality of Chilean listed Firms, 136, Retrieved from http://issm.com/abstract98269.

Ramsay, I., \& Blair, M. (1993). Ownership Concentration, Institutional Investment and Corporate Governance: An Empirical Investigation of 100 Australian Companies. Melbourne University Law Review, 19, 153-194.

Roodposhti, F. R. \& Chashmi, S. A. N. (2010). The impact of corporate governance mechanisms on earnings management. African Journal of Business Management, 5(11), 4143-4151.

Salsiah, M.A., Salleh, N.M., \& Hassan, M.S. (2008). Ownership Structure and Earnings Management in Malaysian Listed Companies: The Size Effect. Asian Journal of Business and Accounting, 1(2), 89-116.

Sandra, A. (2012). Ownership structure and earnings management: Evidence from Portugal. Australasian Accounting Business and Finance Journal, 6(1), 57 - 74

Soongso, S. H. (2004). Ownership Structure and quality of financial Reporting, Department of Accountancy, the University of Illinois at Urbana-Champaign.

Sánchez-Ballesta, J. P., \& García-Meca, E. (2007). Ownership structure, discretionary accruals and the informativeness of earnings. Corporate Governance: An International Review, 15(4), 677-691.

Siregar, S., \& Utama, S. (2008). Type of earnings management and the effect of ownership structure, firm size, and corporate-governance practices: Evidence from Indonesia. The International Journal of Accounting, 43, 55-70.

Tabachnick, B.G. \& Fidell, L.S. (2001). Using Multivariate Statistics, Allyne Bacon, New York.

Usman, S. H., \& Yero, J. I. (2012). Ownership concentration and earnings management practice of nigerian listed conglomerates. American International Journal of Contemporary Research, 2(7), 157-171.

Velury, U., \& Jenkins, D. (2006). Institutional ownership and the quality of earnings. Journal of Business Research, 59, 376-424.

Wang, D. (2006). Founding family ownership and Earnings Management. Journal of Accounting and Research, 44, 112-125.

Warfield, T. D., Wild, J. J., \& Wild, K. L. (1995). Managerial ownership, accounting choices, and informativeness of earnings. Journal of accounting and economics, 20(1), 61-91.

Zhong, K., Gribbin, D. W., \& Zheng, X. (2007). The effect of monitoring by outside blockholders on earnings management. Quarterly Journal of Business and Economics, 37-60. 